\title{
Studi Komparatif Prenatal Yoga dan Senam Hamil terhadap Kesiapan Fisik
}

\author{
Ratih Setio Dewi ${ }^{1}$, Erialdy ${ }^{2}$, Astrid Novita ${ }^{3}$ \\ ${ }^{1,2}$ Akademi Kebidanan Yayasan Perguruan Djubleg Ranuatmadja Jakarta \\ JI. Ipin No. 57 Pondok Labu Cilandak Jakarta Selatan, Telp: (021) 75903085 \\ ${ }^{3}$ Sekolah Tinggi Ilmu Kesehatan Indonesia Maju \\ Jalan Harapan No. 50 Lenteng Agung Jakarta Selatan 12610, Telp. (021) 788-94045 \\ Email: ${ }^{1}$ ratihdewiku@gmail.com, ${ }^{2}$ eri_aldy@yahoo.co.id, ${ }^{3}$ astridnh.by28@gmail.com
}

\begin{abstract}
Abstrak
Berlatih prental yoga dan senam hamil di masa kehamilan merupakan salah satu faktor penunjang dalam upaya membantu ibu hamil dalam menjalani kehamilannya. Prenatal yoga dan senam hamil menjadi kegiatan yang dapat meningkatkan kesiapan fisik pada ibu hamil baik dimasa kehamilan maupun masa persalinanannya.Tujuan penelitian adalah untuk mengetahui efektivitas dari kegiatan prenatal yoga dan senam hamil terhadap kesiapan fisik. Metode penelitian desain kohort prospektif. Sampel sebanyak 60 responden (30 ibu hamil kelompok prenatal yoga dan 30 ibu hamil kelompok senam hamil). Metode analisis data dengan menggunakan Independent $\mathrm{T}$ Test. Hasil penelitian menunjukkan adanya pengaruh prenatal yoga dan senam hamil terhadap kesiapan fisik. Pada hasil uji beda rata-rata menunjukkan pengaruh yang signifikan pada kesiapan fisik ( $F I p=0,005, F 2 p=0,000, F 3 p=0,000$ ). Selanjutnya, hasil uji hipotesis dengan nilai $t$ tabel $-2,048$ bahwa variabel prenatal yoga dan senam hamil pada FI, F2, F3, memiliki pengaruh yang signifikan terhadap kesiapan fisik $(F I=-2,888, F 2=-5,879$ dan $F 3=-5,233)$. Diperlukan adanya peningkatan cakupan yang luas dalam penerapan kegiatan prenatal yoga pada ibu hamil dimasa kehamilannya sehingga dapat menjangkau setiap lapisan pelayanan kesehatan ibu dan anak.
\end{abstract}

Kata kunci : Prenatal Yoga, Senam Hamil, Kesiapan Fisik

\begin{abstract}
Practicing prenatal yoga and gymnastics during pregnancy at the time of pregnancy is one of the supporting factors in an attempt to help pregnant women through her pregnancy. Prenatal yoga and gymnastics during pregnancy into activities that can improve the physical readiness on pregnant women either in the pregnancy or labor. The purpose of the research is to find out the effectiveness of the activities of the prenatal yoga and gymnastics during pregnancy against the physical readiness. Research methods using a prospective cohort design. The sample used as many as 60 respondents (30 pregnant women group prenatal yoga and 30 pregnant women pregnant Gymnastics Group). Methods of data analysis using Independent $T$ Test. Results of the research indicate the influence of prenatal yoga and gymnastics pregnant against physical readiness. Significant result from mean difference test showed significant effects on physical readiness ( $F I p=0.005, F 2$ $p=0.000, F 3 p=0.000$ ). Furthermore, the hypothesis test results with value $t$ table-2.048 that variable prenatal yoga and gymnastics during pregnancy on $F I, F 2, F 3$, have significant influence towards physical readiness $(F I=F 2=2.888-,-5.879$ and F3 $=-5.233$ ). Required an increase in the scope of activities in the implementation of extensive prenatal yoga on expectant mothers in her pregnancy so that it can reach every layer of the maternal and child health services.
\end{abstract}

Keywords : Prenatal yoga, Gymnastics during pregnancy, physical readiness 


\section{Pendahuluan}

Di masa kehamilan, kegiatan yang dilakukan oleh ibu berupa latihan fisik memiliki pengaruh yang baik terhadap janin, kehamilan, berat bayi lahir, mengurangi komplikasi persalinan seperti pengurangan tingkat nyeri dan persalinan lama. Selain latihan fisik, bentuk alternatif yang dapat dilakukan yaitu pemijatan dan terapi energi serta mindbody healing seperti salah satu diantaranya yaitu meditasi/yoga. ${ }^{1}$

Berlatih yoga di masa kehamilan merupakan salah satu faktor penunjang dalam upaya membantu ibu hamil dalam menjalani kehamilannya. Yoga yang dilakukan selama masa kehamilan juga berguna untuk menurunkan terjadinya hasil persalinan yang negatif atau negative birth outcomes. $^{2}$

Hasil penelitian mengungkapkan bahwa prenatal yoga sangat dapat meningkatkan birth outcomes dan pengalaman melahirkan yang baik. Berlatih yoga (termasuk diantaranya latihan fisik postur tubuh, teknik pernafasan, dan meditasi) setiap hari pada wanita hamil dengan usia kehamilan 18 sampai 20 minggu kehamilan sampai waktu persalinan, telah menunjukkan peningkatan rata-rata berat badan lahir yang dilahirkan dan menurunkan kejadian persalinan prematuritas, IUGR, dan kejadian hipertensi kehamilan dibandingkan dengan kelompok ibu hamil yang melakukan kegiatan fisik berjalan kaki dua kali sehari selama 30 menit selama kehamilannya Prenatal yoga juga memiliki manfaat untuk dapat meningkatkan berat badan lahir bayi dan mengurangi kejadian persalinan prematuritas serta terjadinya komplikasi persalinan. Hal ini didasarkan pada hasil penelitian pada 169 ibu hamil yang menerima latihan prenatal yoga selama masa kehamilannya dengan kelompok kontrol sebanyak 166 ibu hamil di Bangalore, India. Hasil penelitian tersebut menunjukkan ibu hamil yang mengalami kelahiran premature sebanyak $14 \%$, sedangkan sebanyak $29 \%$ pada kelompok kontrol. $^{3}$
Selain itu, yoga pada masa kehamilan memiliki manfaat yang besar dalam menjaga kesehatan baik emosi maupun fisik serta menunjukkan penurunan rasa sakit, stress, terjadinya gangguan prenatal dan usia kehamilan yang kecil. Yoga juga dinilai merupakan latihan yang lebih efektif dari berjalan kaki atau standar latihan prenatal lainnya. ${ }^{4}$ Prenatal yoga juga membantu proses persalinan ibu menjadi sebuah pengalaman positif yang ibu alami dengan cara meningkatkan kekuatan otot, peningkatan cadangan energi dan fleksibilitas. Yoga bekerja dengan cara mempersiapkan tubuh wanita untuk menjalani proses persalinan yang akan dilaluinya. Hal ini membantu wanita untuk merasa lebih percaya diri dan mendapatkan keyakinan akan kemampuan tubuhnya untuk untuk bersalin normal. ${ }^{5}$ Meditasi dan yoga dapat mengurangi cidera fisik dan stress psikologis selama menjalani masa kehamilan dan persalinan, termasuk kecemasan dan rasa sakit selama masa persalinan. ${ }^{6}$

Pembuktian hubungan perubahan fisik berupa pengurangan ketidaknyamanan fisik dan keluhan yang selama ini kerap kali terjadi pada ibu hamil dimana diungkapkan bahwa pada kelompok yang melakukan prenatal yoga mengalamgi peningkatan yang signifikan pada segi fisik $(\mathrm{p}<0,001)$, psikologis $\quad(\mathrm{p}<0,003), \quad$ kualitas hidup $(\mathrm{p}<0,001)$, hubungan social $(\mathrm{p}<0,003)$ dan lingkungan sekitar $(\mathrm{p}<0,001){ }^{7}$ Selanjutnya, pada penelitian yang berjudul Effects of $a$ prenatal yoga programme on the discomforts of pregnancy and maternal childbirth self-efficacy in Taiwan diungkapkan bahwa kelompok ibu hamil yang melakukan prenatal yoga dilaporkan mengalami peningkatan yang signifikan terhadap penurunan tingkat ketidaknyamanan ibu selama masa kehamilannya $\quad(\mathrm{p}=0,01) \quad$ dibandingkan dengan kelompok kontrol yaitu ibu hamil yang tidak melakukan latihan prenatal yoga. ${ }^{8}$

Selanjutnya, kegiatan fisik pada masa kehamilan bukan hanya melakukan latihan 
prenatal yoga. Senam hamil menjadi salah satu diantaranya. Senam hamil sendiri memiliki pengertian yaitu suatu latihan yang berguna untuk memperkuat serta mempertahankan elastisitas perut, ligament, otot dasar panggul yang berhubungan dengan proses persalinan. ${ }^{9}$ Senam hamil lebih dulu dikenal oleh masyarakat Indonesia dibandingkan prenatal yoga. Senam hamil mampu memberikan latihan fisik berupa gerakan-gerakan yang dapat membuat ibu hamil siap dalam mempersiapkan fisik maupun mentalnya. Selain itu, senam hamil juga membuat ibu siap menghadapi persalinan yang aman, dan cepat serta spontan sesuai dengan harapan ibu. $^{10}$

Senam hamil ternyata secara keseluruhan akan memberikan outcomes persalinan yang lebih baik dibandingkan dengan ibu hamil yabng tidak melakukan senam hamil. Beberapa kondisi seperti berat badan bayi lahir rendah, kelainan denyut jantung janin, gangguan tali pusat dan mekonium, penurunan tenaga ibu, rasa nyeri persalinan, persalinan prematur, section caesar, asfiksia, stress dan gangguan psikomotor bayi dilaporkan mengalami penurunan pada ibu yang melakukan senam hamil. Selain itu, dengan melakukan senam hamil maka ibu akan merasa rileks serta mampu menguasai keadaan yang pada umumnya akan membuat seorang ibu hamil cemas dalam menghadapi proses persalinan. Hal ini karena ibu yang berlatih senam hamil selama masa kehamilannya telah terlatih untuk melatih kesiapan diri salah satunya yaitu dengan latihan pernafasan. ${ }^{11}$

Beberapa penelitian telah dilakukan untuk mengetahui baik pengaruh senam hamil maupun yoga kehamilan terhadap lama persalinan. Hasil penelitian tersebut mengungkapkan bahwa terdapat hubungan yang signifikan antara senam hamil dengan kejadian persalinan lama (nilai $\mathrm{p}=0,033$ ) dengan OR sebesar 5,5 yang mempunyai makna bahwa dengan melakukan senam hamil maka kejadian persalinan lama dapat berkurang sebesar 5,5 kali dibandingkan pada ibu yang tidak mengikuti senam hamil. $^{12}$ Senam hamil juga memiliki pengaruh pada lamanya persalinan kala I dan kala II dengan nilai $\mathrm{p}=0,001$. $^{13}$ Selanjutnya, hasil penelitian yang dilakukan pada kelompok yang diberi latihan prenatal yoga pada kehamilan mengalami durasi persalinan kala I yang lebih singkat dibandingkan kelompok yang tidak melakukan latihan prenatal yoga pada kehamilan. $^{5}$

Berdasarkan data yang diperoleh dari survei pendahuluan di salah satu fasilitas kesehatan yang menyediakan akses bagi ibu hamil untuk melakukan prenatal yoga yaitu di Klinik Utama Rawat Inap Depok Jaya Kota Depok pada bulan Oktober 2016 menunjukkan bahwa sekitar 169 ibu hamil atau sekitar $89,4 \%$ dari total $189 \mathrm{ibu}$ hamil yang melakukan prenatal yoga mendapatkan hasil persalinan yang optimal. Dari 169 ibu hamil yang melakukan prenatal yoga terdapat sekitar 26 atau $15,3 \%$ ibu hamil mengalami kondisi kehamilan patologis (kehamilan sungsang dan usia resiko tinggi) dari latihan prenatal yoga justru mengarah kepada hasil yang positif

Sementara itu, berdasarkan survei pendahuluan di Bidan Praktik Mandiri Bidan Sri Hayuningsih Citayam Kota Depok terhadap ibu hamil yang mengikuti senam hamil yaitu sebanyak 25 ibu hamil dari 63 ibu hamil pada periode bulan Juli Desember 2016 ditemukan bahwa sebanyak 23 ibu bersalin normal (92\%) Oleh karena itu baik prenatal yoga maupun senam hamil sangat direkomendasikan sebagai salah satu usaha untuk meningkatkan kualitas kesehatan ibu hamil. Berdasarkan uraian tersebut maka penulis tertarik melakukan penelitian mengenai studi komparatif efektivitas prenatal yoga dan senam hamil terhadap kesiapan fisik di wilayah Kota Depok tahun 2017.

Tujuan penelitian ini adalah untuk mengetahui efektivitas prenatal yoga pada kelompok ibu hamil yang mengikuti kelas prenatal yoga dan senam hamil terhadap kesiapan fisik. 


\section{Metode}

Desain penelitian ini menggunakan metode kohor dengan pendekatan studi prospektif yang merupakan penelitian epidemiologis analitik observasional dimana studi ini akan mengkaji lebih lanjut hubungan antara kelompok paparan dan kelompok resiko dengan cara melakukan pembandingan tersebut berdasarkan status resiko. $^{14}$

Populasi yang digunakan yaitu ibu hamil primigravida yang melakukan pemeriksaan di Klinik Rawat Inap Utama Depok Jaya, BPM Bidan Sri Hayuningsih, dan BPM Bidan Dewi, pada bulan Januari Februari tahun 2017. Teknik sampling yang digunakan adalah total sampling dengan besar sampel sebanyak 60 responden yang dibagi menjadi 2 kelompok yaitu kelompok terpapar (ibu hamil melakukan prenatal yoga ) dan kelompok kontrol (ibu hamil melakukan senam hamil). Sedangkan kiteria inklusi penelitian ini yaitu ibu hamil primigravida minimal usia 35 minggu masa kehamilan, rutin melakukan prenatal yoga minimal 6 kali melakukan prenatal yoga yang terprogram dari usia kehamilan 28 minggu, tanpa komplikasi pada masa kehamilannya dan bersedia menjadi responden.

Selanjutnya, untuk kriteria matching pada penelitian ini yaitu setara antara jumlah kelompok terpapar dan kelompok 60 kontrol yaitu 30 ibu hamil terpapar prenatal yoga dan $30 \mathrm{ibu}$ hamil terpapar senam hamil, setara untuk jumlah usia ibu hamil untuk masing-masing kelompok berusia antara 20-35 tahun, setara untuk jumlah paritas ibu hamil untuk masingmasing kelompok yaitu 30 ibu hamil berstatus primigravida, setara untuk jumlah minimal usia kehamilan pada kelompok terpapar dan kelompok kontrol yaitu minimal 35 minggu, setara untuk jumlah melakukan prenatal yoga minimal 6 kali melakukan prenatal yoga yang terprogram dari usia kehamilan 28 minggu, setara untuk jumlah minimal pemeriksaan kehamilan pada kelompok terpapar dan kelompok kontrol yaitu minimal 4 kali pemeriksaan kehamilan, setara untuk level kesiapan fisik pada kelompok terpapar (ibu hamil melakukan prenatal yoga) dan kelompok kontrol (ibu hamil melakukan senam hamil) yaitu dengan gangguan level sedang.

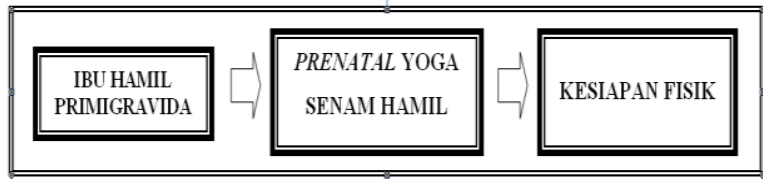

Gambar. 1. Kerangka Konsep Penenlitian

Berdasarkan gambar 1 maka kerangka konsep penelitian ini dilakukan pengolahan data untuk mengetahui pengaruh prenatal yoga dan senam hamil terhadap kesiapan fisik

Alat pengumpulan menggunakan lembar pengumpulan data demografi untuk mengumpulkan data karakteristik subjek dan keikutsertaan program prenatal yoga, lembar pengumpulan data kesiapan fisik dengan mengunakan rating scale yang terdiri dari 4 skala penilaian. Cara penilaian untuk pernyataan tidak ada (nilai 0 ), ringan (nilai 1), sedang(nilai 2), berat (nilai 3) dan sangat berat (nilai 4)

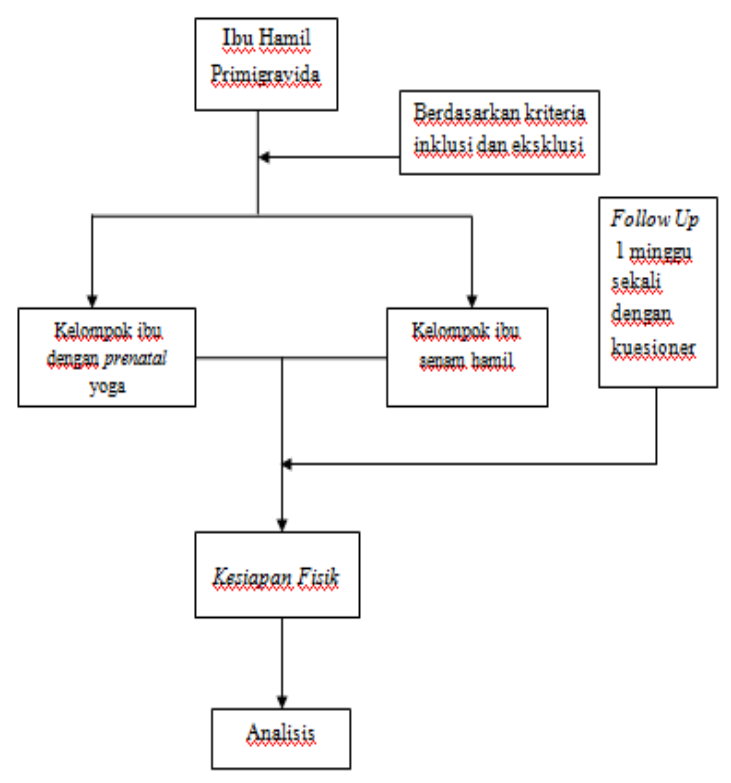

Gambar. 2. Proses Pengumpulan Data 
Selanjutnya gambar 2 menjelaskan proses pengumpulan data dilakukan dengan cara pemantauan (Follow Up) 1 minggu sekali dengan total Follow up sebanyak 3 kali dengan menggunakan kuesioner yang tersedia. Selama dilakukannya Follow up1 (F1), Follow up2 (F2), dan Follow Up3 (F3), tidak ditemukan drop out .

Analisis data yang digunakan adalah uji t tidak berpasangan dan analisis data mengunakan aplikasi SPSS versi 16.0.

\section{Hasil}

Tabel 1. Karakteristik Responden

\begin{tabular}{llllll}
\hline \multirow{2}{*}{ Variabel } & Kategori & \multicolumn{2}{c}{$\begin{array}{c}\text { Prenatal } \\
\text { Yoga }\end{array}$} & \multicolumn{2}{c}{$\begin{array}{c}\text { Senam } \\
\text { Hamil }\end{array}$} \\
\cline { 3 - 6 } & & n & \% & n & \% \\
\hline Usia Ibu & 20-30 th & 19 & 63,3 & 14 & 46,6 \\
& $31-35$ th & 11 & 36,6 & 16 & 53,3 \\
Usia & 28-36 mgg & 18 & 60 & 24 & 80 \\
Kehamilan & 37-42 mgg & 12 & 40 & 6 & 20 \\
Jml & 6 kali & 22 & 73,3 & 26 & 86,6 \\
Latihan & 7-10 kali & 8 & 26,6 & 4 & 13,3 \\
& >10 kali & 0 & 0 & 0 & 0 \\
Pendidikan & Rendah & 0 & 0 & 0 & 0 \\
& Menengah & 11 & 36,6 & 24 & 80 \\
Pekerjaan & Tinggi & 19 & 63,3 & 6 & 20 \\
& PNS & 7 & 23,3 & 0 & 0 \\
Sosial & Swasta & 17 & 56,6 & 12 & 26,6 \\
ekonomi & IRT & 6 & 20 & 18 & 73,3 \\
& Rendah & 0 & 0 & 12 & 40 \\
& Tinggi & 30 & 100 & 18 & 60 \\
\hline
\end{tabular}

Pada tabel 1 menunjukkan hasil berupa usia responden mayoritas 20-30 tahun yaitu sebanyak 33 orang (55\%), usia kehamilan antara kedua kelompok mayoritas antara 28-36 minggu yaitu 42 orang $(70 \%)$. Sedangkan untuk jumlah mayoritas mengikuti latihan sebanyak 6 kali latihan yaitu 48 orang (80\%). Selanjutnya pendidikan ibu menunjukkan mayoritas ibu berpendidikan menengah (SMP dan SMA) yaitu sebanyak 35 orang (58,3\%). Sebanyak
29 orang $(48,3 \%)$ responden bekerja sebagai pegawai swasta dan mayoritas responden memiliki sosial ekonomi tinggi $(\geq$ Rp 3.297.489,-) yaitu sebanyak 48 orang $(80 \%)$.

Berdasarkan tabel 2 hasil skor ratarata baik kelompok ibu prenatal yoga maupun senam hamil membentuk pola perubahan kearah yang positif dengan nilai mean semakin menurun dari tiap follow up yang dilakukan. Hal ini disebabkan oleh sebaran nilai skor variabel memiliki alur semakin kecil maka skor pada setiap variabel semakin baik. Hasil sebaran nilai skor kesiapan fisik ibu hamil pada saat follow up 1 menunjukkan rata-rata yang cukup tinggi pada kedua kelompok, yaitu 17,30 pada kelompok terpapar dan 20,30 pada kelompok kontrol. Skor kesiapan fisik pada kelompok terpapar relatif lebih tinggi dari pada kelompok kontrol.Sedangkan pada sebaran nilai skor kesiapan fisik ibu hamil pada follow up2 pada kedua kelompok menunjukkan peningkatan kesiapan fisik ibu hamil, untuk kelompok terpapar memiliki rata-rata skor yaitu 11,77, sedangkan kelompok kontrol memiliki rata-rata skor yaitu 17,93. Selanjutnya, pada follow up 3 skor rata-rata kesiapan fisik ibu prenatal yoga yaitu 11,23 dan kelompok ibu hamil sebesar 16,67.

Analisa bivariat dilakukan bertujuan untuk menguji hipotesis penelitian yaitu apakah prenatal yoga dan senam hamil mempengaruhi skor kesiapan fisik. Selanjutnya, berdasarkan tabel 3 menunjukkan Group statistic pada follow up kesiapan fisik 1, 2 dan 3 untuk kelompok prenatal yoga dan kelompok senam hamil.

Tabel 2. Skor Kesiapan Fisik

\begin{tabular}{ccccccccc}
\hline \multirow{2}{*}{$\begin{array}{c}\text { Follow } \\
\text { up }\end{array}$} & \multicolumn{9}{c}{ Prenatal Yoga } & \multicolumn{4}{c}{ Senam Hamil } \\
\cline { 2 - 8 } & Mean & Median & SD & Min-Max & Mean & Median & SD & Min-Max \\
\hline Ke-1 & 17,3 & 18,00 & 4,036 & $11-25$ & 20,30 & 21,00 & 4,010 & $12-29$ \\
$\mathrm{Ke}-2$ & 11,77 & 11,50 & 3,645 & $6-19$ & 17,93 & 18,00 & 4,441 & $10-27$ \\
$\mathrm{Ke}-3$ & 11,23 & 10,50 & 3,380 & $5-19$ & 16,67 & 15,50 & 4,574 & $9-26$ \\
\hline
\end{tabular}


Pada tabel 4 menunjukkan bahwa hasil analisis dengan menggunakan uji independent $T$ Test menunjukkan hasil ratarata nilai pada follow up 1,2 dan 3 antara kelompok ibu prenatal yoga dan kelompok ibu senam hamil memiliki perbedaan secara signifikan terhadap variabel kesiapan fisik.

Berdasarkan data pada tabel 4 juga turut menunjukan hasil uji hipotesis dengan derajat keabsahan $\mathrm{df}=\mathrm{n}-2$ yakni $30-2=28$ dengan taraf signifikasi 0,05 atau $5 \%$. Berdasarkan $t$ tabel maka nilai $t$ tabel yaitu -2,048.Sehingga hasil dari pengujian tersebut menunjukkan bahwa variabel yoga dan senam hamil pada F1, F2, F3, memiliki pengaruh yang signifikan terhadap kesiapan fisik $(F 1=-2,888, F 2=-5,879$ dan $F 3=-$ 5,233).

\section{Pembahasan}

\section{Hubungan Prenatal Yoga terhadap Kesiapan Fisik}

Kesiapan fisik ibu dalam menjalani kehamilan hingga proses persalinan perlu dilatih dengan cara melakukan latihan fisik.
Latihan fisik memiliki pengaruh yang baik terhadap janin, dan kesehatan ibu serta mengurangi komplikasi persalinan. Bentukbentuk kegiatan alternatif yang dapat dilakukan dimasa kehamilan dan memiliki manfaat yang besar diantaranya yaitu pemijatan dan meditasi/yoga. ${ }^{1}$

Tabel 3. Group statistic pada follow up kesiapan fisik 1, 2 dan 3

\begin{tabular}{llcccc}
\hline & Latihan & n & Mean & SD & $\begin{array}{c}\text { SE } \\
\text { Mean }\end{array}$ \\
\hline Fisik & Prenatal & 30 & 17,30 & 4,036 & 0,737 \\
F1 & Yoga & & & & \\
& $\begin{array}{l}\text { Senam } \\
\text { Hamil }\end{array}$ & 30 & 20,30 & 4,010 & 0,732 \\
Fisik & Prenatal & 30 & 11,77 & 3,645 & 0,666 \\
F1 & Yoga & & & & \\
& Senam & 30 & 17,93 & 4,441 & 0,811 \\
& Hamil & & & & \\
Fisik & $\begin{array}{l}\text { Prenatal } \\
\text { F1 }\end{array}$ & Yoga & 11,23 & 3,380 & 0,617 \\
& Senam & 30 & 16,67 & 4,574 & 0,835 \\
& Hamil & & & & \\
\hline
\end{tabular}

Tabel 4. Hasil Uji Independen T Test follow up kesiapan fisik F1, F2 dan F3

\begin{tabular}{|c|c|c|c|c|c|c|c|c|c|c|}
\hline & & $\begin{array}{r}\text { Leven } \\
\text { for } \mathrm{Ec} \\
\mathrm{Var}\end{array}$ & $\begin{array}{l}\text { s Test } \\
\text { ity of } \\
\text { nce }\end{array}$ & \multicolumn{7}{|c|}{ t-Test for Equity Of Means } \\
\hline & & \multirow[t]{2}{*}{$\mathrm{F}$} & \multirow[t]{2}{*}{ Sig. } & \multirow[t]{2}{*}{$\mathrm{t}$} & \multirow[t]{2}{*}{ df } & \multirow{2}{*}{$\begin{array}{l}\text { Sig (2- } \\
\text { tailed) }\end{array}$} & \multirow{2}{*}{$\begin{array}{c}\text { Mean } \\
\text { Difference }\end{array}$} & \multirow{2}{*}{$\begin{array}{l}\text { Std. Error } \\
\text { Difference }\end{array}$} & \multicolumn{2}{|c|}{$\begin{array}{l}\text { 95\% CI of the } \\
\text { Difference }\end{array}$} \\
\hline & & & & & & & & & Lower & Upper \\
\hline \multirow[t]{2}{*}{$\begin{array}{l}\text { Fisik } \\
\text { F1 }\end{array}$} & $\begin{array}{l}\text { Equal } \\
\text { variances } \\
\text { assumed }\end{array}$ & 0,125 & 0,725 & $-2,888$ & 58 & 0,005 & $-3,000$ & 1,039 & $-5,079$ & $-0,921$ \\
\hline & $\begin{array}{l}\text { Equal } \\
\text { variances } \\
\text { non } \\
\text { assumed }\end{array}$ & & & $-2,888$ & 57,998 & 0,005 & $-3,000$ & 1,039 & $-5,079$ & $-0,921$ \\
\hline \multirow[t]{2}{*}{$\begin{array}{l}\text { Fisik } \\
\text { F2 }\end{array}$} & $\begin{array}{l}\text { Equal } \\
\text { variances } \\
\text { assumed }\end{array}$ & 0,878 & 0,353 & $-5,879$ & 58 & 0,000 & $-6,167$ & 1,049 & $-8,266$ & $-4,067$ \\
\hline & $\begin{array}{l}\text { Equal } \\
\text { variances } \\
\text { non } \\
\text { assumed }\end{array}$ & & & $-5,879$ & 55,879 & 0,000 & $-6,167$ & 1,049 & $-8,266$ & $-4,067$ \\
\hline \multirow[t]{2}{*}{$\begin{array}{l}\text { Fisik } \\
\text { F3 }\end{array}$} & $\begin{array}{l}\text { Equal } \\
\text { variances } \\
\text { assumed }\end{array}$ & 2,752 & 0,103 & $-5,233$ & 58 & 0,000 & $-5,433$ & 1,038 & $-7,512$ & $-3,355$ \\
\hline & $\begin{array}{l}\text { Equal } \\
\text { variances } \\
\text { non } \\
\text { assumed }\end{array}$ & & & $-5,233$ & 53,400 & 0,000 & $-5,433$ & 1,038 & $-7,512$ & $-3,355$ \\
\hline
\end{tabular}


Melakukan kegiatan prenatal yoga terhadap kesiapan fisik ibu hamil diwujudkan dalam bentuk terciptanya kenyaman ibu hamil dalam keluhankeluhan yang kerap kali terjadi di masa kehamilan diantaranya seperti pembengkakan anggota tubuh dan kram. Selain itu, kegiatan prenatal yoga ini juga dalat meningkatkan sistem pencernaan ibu hamil, mengurangi rasa mual, membantu meningkatkan nafsu makan, meningkatkan energi, meredakan ketegangan sekitar serviks dan jalan rahim, membantu posisi dan pergerakan janin ibu sehingga dapat mempermudah proses persalinan ibu. Selain itu, manfaat prenatal yoga pada ibu nifas juga tampak pada peningkatan proses tubuh dalam upaya pengembalian uterus, perut dan postur tubu sesuai jalannya kelahiran serta mempercepat proses pengembalikan fungsi dan bentuk alat reproduksi seperti sebelum kehamilan. $^{15}$ Pembuktian hubungan perubahan fisik berupa pengurangan ketidaknyamanan fisik dan keluhan yang selama ini kerap kali terjadi pada ibu hamil telah dilakukan dimana diungkapkan bahwa pada kelompok yang melakukan prenatal yoga mengalamgi peningkatan yang signifikan pada segi fisik $(\mathrm{p}<0,001)$, psikologis $(\mathrm{p}<0,003)$, kualitas hidup $(\mathrm{p}<0,001)$, hubungan social $(\mathrm{p}<0,003)$ dan lingkungan sekitar $(\mathrm{p}<0,001)^{7}$

Sejalan dengan hal tersebut maka pada penelitian yang berjudul Effects of a prenatal yoga programme on the discomforts of pregnancy and maternal childbirth self-efficacy in Taiwan juga diungkapkan bahwa kelompok ibu hamil yang melakukan prenatal yoga dilaporkan mengalami peningkatan yang signifikan terhadap penurunan tingkat ketidaknyamanan ibu selama masa kehamilannya $\quad(p=0,01) \quad$ dibandingkan dengan kelompok kontrol yaitu kelompok yang tidak melakukan latihan prenatal yoga. 8

Manfaat prenatal yoga juga dapat dirasakan secara fisik pada tubuh manusia dimana seringkali rasa ketidaknyamanan gerak tubuh, otot dan sendi. Melakukan prenatal yoga akan membuat otot-otot tubuh berkembang, diantaranya yaitu fokus dalam kesehatan tulang belakang, kekuatan dan fleksibilitas. Latihan prenatal yoga pada ibu hamil ini akan meningkatkan sirkulasi darah dan syaraf meningkat sehingga pasokan nutrisi dan oksigen terpenuhi. ${ }^{15}$

Berdasarkan hasil observasi yang telah penulis lakukan maka sangat terlihat bahwa kegiatan prenatal yoga bagi ibu hamil memiliki manfaat yang besar pada kondisi fisik ibu. Ibu hamil yang melakukan prenatal yoga merasa bahwa kondisi fisik tubuh nya lebih bugar, tubuh lebih ringan hingga membuat ibu lebih nyaman menjalani masa kehamilannya. Mayoritas ibu hamil yang melakukan prenatal yoga mengungkapkan bahwa keluhan nyeri punggung yang dirasakan selama masa kehamilan berangsung-angsur berkurang bahkan menghilang seiring dengan keikutsertaan ibu dalam kegiatan prenatal yoga. Oleh karena itulah, maka hubungan keterikatan antara yoga dengan kesiapan fisik pun sangat berhubungan erat.

\section{Hubungan Senam Hamil dengan Kesiapan Fisik}

Hal ini mengungkapkan pula akan adanya efek berupa perubahan yang positif pada kesiapan ibu dengan melakukan senam hamil. Melakukan senam hamil menguatkan sistem perototan tubuh dan sendi-sendi di waktu masa kelahiran janin. Seiring dengan kemampuan ibu yang semakin baik dalam menjalani latihan senam hamil maka kepercayaan diri ibu pun tubuh maka ibu akan siap untukbersalin. Selain itu, elastisitas otot-otot panggul, ligament, mencegah varises, dan peningkatan sistem pernafasan dapat diperoleh dari latihan senam hamil sehingga faktor-faktor yang mempersulit jalanannya persalinan dapat teratasi karena kesiapan ibu yang di dapatkan dari latihan-latihan senam hamil. ${ }^{16}$ Studi meta analisis dengan judul Influence of prenatal physical activity on the course of labour and 
delivery according to the new Polish standard for perinatal care juga mengungkapkan bahwa kegiatan fisik selama masa kehamilan seperti senam hamil mampu meminimalisasi dampak negatif dari tindakan-tindakan intervensi yang juga akan dikurangi dengan kesiapan diri ibu hamil yang melakukan senam hamil serta senam hamil juga menjadi sebuah standar pelayanan pada masa kehamilan yang dapat diterapkan pada kegiatan penunjang kesehatan ibu hamil. ${ }^{18}$

Oleh karena itu, menurut asumsi penulis bahwasannya senam hamil memang memiliki manfaat yang besar untuk mempersiapkan ibu hamil menghadapi persalinan, salah satunya adalah mempersiapkan diri dari segi jasmani atau kesiapan fisik tubuh ibu. Beberapa gerakan dalam senam hamil menjurus kepada peregangan otot-otot pada tubuh ibu khusus nya pada kaki sehingga penurunan ketidaknyamanan serta keluhan yang seringkali terkait dengan kondisi kesiapan fisik pada ibu hamil dapat dengan sangat efektif mengurangi berbagai keluhan tersebut. Berdasarkan hal tersebut maka senam hamil juga menjadi salah satu bagian dari sekian banyak latihan fisik pada masa kehamilan yang menjadi pilihan efektik untuk mencapai kesiapan diri ibu hamil dari segi kondisi kesiapan fisik tubuh ibu

\section{Hubungan Prenatal Yoga dan Senam Hamil Terhadap Kesiapan Fisik Ibu Hamil}

Kegiatan fisik prenatal yoga merupakan relasi antara yoga dan anatomi tubuh, dimana keduanya memiliki ketekaitan yang berasal dari pemikiran yang cukup sederhana yaitu adanya prinsip terdalam dalam yoga yang didasarkan atas penghargaan atas sistem tubuh manusia bermula. Subjek studi yoga adalah diri sendiri dan diri sendiri berdiam di dalam fisik Manfaat dari latihan yoga secara teratur sangat membantu dalam menjaga kesehatan dan kemudahan ibu dalam menjalani masa persalinan dan nifas dimana prenatal yoga akan membuat sistem otot tubuh menjadi lentur terutama di daerah jalan lahir. Hal ini penting untuk diketahui karena dengan melakukan prenatal yoga maka kecemasan dan kepanikan yang kerapkali melanda ibu akan berkurang sehingga makin menegangkan otot jalan lahir ibu yang nantinya justru akan membuat proses persalinan berjalan lancar 19

Gerakan peregangan otot dalam prenatal yoga dapat meminimalisasi bahkan menghilangkan ketidaknyamanan yang seringkali dirasakan selama masa kehamilan seperti hearth burn, nyeri di pinggul, atau tulang rusuk, keram dikaki atau sakit kepala. Selain itu, sirkulasi oksigen darah memiliki ketergantungan pada kondisi otot tubuh. Prenatal yoga dapat membantu untuk memastikan bahwa janin dalam kandungan ibu mendapatkan semua yang diperlukannya untuk tumbuh sehat dan kuat. Hal ini ditunjang karena gerakan-gerakan dalam latihan prenatal yoga dapat membantu memperlancar pasokan oksigen, nutrisi dan vitamin dan makanan ke janin. ${ }^{15}$

Senam hamil juga memiliki manfaat yang besar dari segi kesiapan fisik namun senam hamil lebih memfokuskan gerakan pada kelenturan tubuh yang diperlukan pada proses persalinan dan pengaturan pernafasan yang akan memberikan manfaat yang besar pada proses persalinan. Sehingga gerakan-gerakan senam hamil dirasakan lebih ringan dan sederhana dibandingkan dengan gerakan yang dilakukan dalam latihan prenatal yoga. ${ }^{20}$

Berdasarkan hasil observasi yang telah penulis lakukan maka tampak bahwa berlatih yoga maupun senam hamil selama masa kehamilan memberikan manfaat yang besar serta menjadi pilihan calon ibu untuk menjalani kehamilan yang lebih nyaman, mempersiapkan persalinan yang alami, fase pemulihan pasca bersalin yang lebih cepat, dan bayi lahir sehat. Namun berdasarkan hasil perhitungan skor rata-rata prenatal yoga dibandingkan dengan senam hamil menunjukkan adanya perbedaan yang signifikan antara kesiapan fisik ibu yang 
melakukan latihan prenatal yoga dengan ibu yang melakukan latihan senam hamil. Hal ini didasari adanya gerakan-gerakan khusus didalam prenatal yoga yang bertujuan menguatkan otot-otot dan organ-organ tubuh yang berkaitan dengan kehamilan dan kelahiran.Latihan ini membentuk kesiapan fisik ibu hamil untuk mempersiapkan diri dari segi fisik dan stamina ibu hamil menuju persalinan.

Salah satu latihan fisik dalam prenatal yoga yaitu Asanas (postur yoga) yang telah dimodifikasi untuk ibu hamil. Latihan Asana ini memiliki manfaat yang besar yaitu mengatasi rasa sakit persalinan, mengatasi keluhan fisik selama kehamilan dan pasca kelahiran dan memberikan waktu untuk memperbaharui energy tubuh serta menghilangkan kondisi lelah tubuh saat kehamilan, kelahiran dan nifas. Pada sesi latihan prenatal yoga yang didasarkan pada observasi yang penulis lakukan bahwa ibu hsmil yang melakukan prenatal yoga tampak lebih berkeringat dan mengeluarkan tenaga lebih dibandingkan dengan saat melakukan latihan senam hamil. Kondisi ini menjadi poin penting dalam perbandingan antara kegiatan prenatal yoga dan senam hamil sehingga menunjukkan perbedaan yang signifikan pada kesiapan fisik ibu prenatal. Gerakan dalam latihan prenatal yoga tampak memiliki intensitas latihan yang lebih serta memiliki variasi gerakan yang berfokus pada upaya peregangan otot-otot hingga tercapainya kondisi relaksasi yang dirasakan oleh ibu dibandingkan dengan gerakan yang dilakukan pada saat melakukan latihan senam hamil yang lebih ringan intensitas gerakannya.

Selanjutnya, teknik-teknik yang dilakukan dalam latihan prenatal yoga memiliki manfaat dalam peningkatan kejernihan pikiran, kesempurnaan teknik pernafasaan serta pada akhirnya bertujuan untuk pencapaian kesehatan tubuh ibu. Latihan prenatal yoga terdiri dari beberapa komponen diantaranya yaitu "Asanas". Asanas menjadi bagian dari latihan yang bertujuan meningkatkan kekuatan fisik, fleksibilitas perototan tubuh dan meningkatkan daya tahan tubuh ibu hamil. Selain itu, kegunaan asanas dalam latihan prenatal yoga juga dapat mempengaruhi kerja kelenjar endokrin dalam upaya menekan pengeluaran hormon stress ibu yang akan menimbulkan ketegangan pada ibu hamil. Asanas juga dapat meningkatkan jumlah hormon relaksan yang akan membentuk kestabilan emosi ibu. Dengan demikian apabila seorang ibu hamil melakukan teknik ini dengan baik maka secara otomatis akan menciptakan keseimbangan emosional diri dan terciptanya ketenangan yang mampu melemaskan otot tubuh ibu yang tegang dan menjadi lebih lentur. Kelenturan otot pada ibu hamil ini juga memiliki dampak positif dimana kekakuan otot yang kerap kali dirasakan oleh ibu menjadi hilang, otot ibu menjadi nyaman selama mejalani proses kehamilan dan tentu saja akan mampu memperlancar jalannya proses persalinan bayinya $^{15}$

Melaksanakan kegiatan latihan prenatal yoga pada ibu hamil merupakan metode yang tepat yang diberikan dan diteima oleh ibu dalam menghadapi proses persalinannya. Kegiatan prenatal yoga ini mampu mengingkatkan kenyaman ibu, menjadikan wakru bersalin menjadi lebih singkat, mengurangi resiko persalinan lama, meningkatkan berat badan lahir bayi, mengurangi risiko kejadian prematuritas dan partummbuhan janin terhambat. Melakukan latihan prenatal yoga juga dapat memberikan kepastian pada ibu dalam mengurangi ketengangan di area sekitar leher lahir dan jalan lahir serta mampu membuat panggul ibu lebil luas. Sehingga dengan demikian prenatal yoga ini dapat memastikan bahwa persalinan ibu akan berjalan dengan mulus dan lancar. Disamping itu, untuk dapat ibu hamil ketahui, bahwasannya kegiatan latihan yoga tidak hanya dilakukan oleh orang-orang yang menginginkan kegiatan berupa meditasi saja, namun kini kegiatan yoga dapat dilakukan oleh semua lapisan usia masyarakat diantaranya yaitu dapat 
dilakukan oleh ibu pada masa kehamilan dan ibu pasca persalinan. ${ }^{3}$

Prenatal yoga diyakini membuat asuhan yang terpusat pada ibu. Hal ini bermakna suatu model asuhan yang dilakukan dengan metode pendekatan perempuan sebagai pusat asuhan yang berlandaskan pada kewajiban pemberi asuhan dalam pemberian hak dasar perempuan berlandaskan evidence based non intervensi dengan didasarkan pada fisiologi normal kehamilan, persalinan, nifas, menyusui serta perhatian terhadap kebutuhan dasar perempuan agar derajat kesehatan ibu dan bayi tercapai. ${ }^{21}$

Latihan prenatal yoga dapat membantu ibu hamil dalam upaya menyelaraskan asuhan dengan prinsip women center care atau asuhan yang terpusat pada ibu. Hal ini dikarenakan dengan melakukan latihan prenatal yoga maka ibu akan merasakan perasaan rileks serta perasaan menikmati jalannya proses persalinan. Prenatal yoga mengajarkan bagaimana ibu dapat mengatur irama pernafasannya dengan baik melalui latihan teknik pernafasan yang tepat sehingga ibu akan terbantu dalam kesiapan diri menghadapi proses persalinan normal. Teknik pernafasan Ujayyi (teknik pernafasan tenggorokan dalam) menjadi salah satu teknik yang dilatih pada ibu hamil dalam fase kala satu persalinan dengan tujuan mencegah ibu merasa kelelahan sehingga tenaga ibu menjadi penuh dan cukup untuk melanjutkan fase kala dua persalinan. Sedangkan pada masa kehamilan teknik ini pun membantu mengoptimalkan pertumbuhan plasenta sehingga bayi dapat lahir dengan berat badan normal. Manfaat prenatal yoga lainnya adalah memperbaiki produksi ASI sehingga ibu bisa segera melakukan inisiasi menyusu dini untuk memulai kegiatan pemberian ASI eksklusif pada banyinya. Hal inilah yang akhirnya membuat kegiatan prenatal yoga sejalan dengan prinsip asuhan yang berpusat pada ibu. ${ }^{15}$

Berdasarkan asumsi penulis bahwa melakukan latihan prenatal yoga berisi kegiatan yang berkelanjutan dimana kegiatan prenatal yoga tidak hanya dilakukan sekali saja, tetapi yoga dapat dilakukan berulang-ulang kali maka kegiatan prenatal yoga bukan hanya semata-mata untuk mempersiapkan proses persalinan saja, tetapi Prenatal yoga juga dapat diterapkkan pada semua kondisi wanita. Hal ini sesuai dengan konsep dari prenatal yoga yang juga memiliki keselarasan dengan filosofi asuhan pada ibu hamil lainnya yaitu asuhan yang berkelanjutan (Continuity of Care). Asuhan yang diberikan pada ibu hamil secara berkelanjutan (Continuity of Care) dan dapat berlaku pada semua bagian siklus kehidupan wanita. $^{21}$

Berdasarkan hasil pemantauan penulis juga terungkap bahwa kegiatan prenatal yoga sangat memungkinkan untuk menjadi bagian dari program yang akan membantu mempersiapkan calon ibu menghadapi persalinannya secara fisik juga mental. Prenatal yoga dapat dilakukan secara mandiri (meditasi) atau dengan bantuan instruktur yang berpengalaman. Di masa kehamilan, prenatal yoga juga bermanfaat dalam upaya meringkan kan edema dan kram, membantu pergerakan dan posisi janin, meningkatkan sistem pencernaan dan nafsu makan ibu, meningkatkan energi, mengurangi perasaan mual yang sering ibu rasakan, meredakan ketegangan di sekitar leher rahim dan jalan lahir yang pada akhirnya dapat membuka pintu panggul (pelvis) untuk mempermudah dan memperlancar jalannya proses persalinan.

Hal ini dimungkinkan karena seperti yang telah diketahui bahwa manfaat prenatal yoga dengan berbagai teknik pernafasan yang dilakukan dapat mempersingkat lamanya proses persalinan sehingga dapat mencegah terjadinya kejadian partus lama atau persalinan lama. Latihan yoga juga dapat dilakukan pula pada masa nifas. Pada masa nifas latihan yoga akan membantu proses pemulihan organ-organ reproduksi. Selain itu yoga yang dilakukan pada masa nifas juga 
bermanfaat untuk mengurangi kecemasan, ketegangan dan ketidaknyamana. Pelaksanaan yoga pada masa nifas dapat dilakukan pada minggu ke 6 masa kehamilan dengan syarat ibu nifas dalam kondisi baik tanpa ada komplikasi paska persalinan. Yoga pada mas nifas ini juga memiliki manfaat lain yaitu mengembalikan bentuk tubuh ibu seperti sebelum hamil.

Kemudian kegiatan yoga bukan hanya dapat dilakukan dimasa kehamilan namun dapat juga dilakukan pada masa nifas. Postnatal yoga atau yoga pada masa nifas memiliki kesamaan dengan prenatal yoga, dimana kedua latihan ini memiliki teknik pernafasan yang berupaya untuk menjernihkan pikiran, mengatasi kelelahan, membantu payudara ibu berproduksi secara maksimal. Kegiatan prenatal yoga maupun postnatal yoga memiliki keunggulankeunggulan yang sangat bermanfaat bagi ibu dalam menjalani rangkaian fase kehidupannya sebagai wanita. Kegiatan yoga yang membantu ibu melenturkan otototot membuat kesiapan fisik ibu hamil dengan optimal.

Sementara itu, peran bidan dalam pelaksanaan prenatal ataupun postnatal yoga yaitu sebagai partnership atau rekan pendamping ibu hamil yang berkesinambungan dengan prinsip pelayananan yang berkelanjutan sehingga dengan demikian ibu hamil yang dibantu oleh bidan dalam latihan prenatal yoga dapat bersalin dengan normal. ${ }^{15}$

Selanjutnya, dalam menjalani proses latihan prenatal yoga, dipastikan untuk ibu mempersiapkan diri secara fisik. Hal ini terjadi karena kekuatan otot tubuh ibu dipersiapkan dalam rangka persiapan diri menjelang persalinan dan juga dapat bermanfaat mengatasi rasa nyeri yang juga merupakan tujuan dari kegiatan latihan pernafasan yang dilakukan selama kegiatan prenatal yoga. Latihan prenatal yoga membantu ibu melepaskan tekanan pada setiap kontraksi yang terasa selama proses persalinan serta melatih pernafasan ibu yang berirama sehingga mampu membantu ibu dalam beradaptasi dengan kontraksi selama masa persalinan. Sehingga dengan demikian ibu mampu mengatasi rasa sakit selama proses persalinan.

Oleh karena itu, berdasarkan uraian diatas maka prenatal yoga dinilai lebih memiliki keunggulan dan manfaat yang besar dibandingkan dengan kegiatan latihan sejenis yaitu khususnya senam hamil. Hal ini didukung dengan hasil observasi yang penulis lakukan bahwa ibu yang melakukan latihan prenatal yoga lebih menunjukkan sikap kepercayaan diri dan citra tubuhnya.Ibu juga merasa lebih bugar dengan sesi latihan asana karena otot-otot tubuh ibu menjadi lebih rileks. Sedangkan keunggulan yoga lainnya yaitu terlihat pada kondisi ibu yang menikmati jalannya kehamilan serta menikmati setiap kebersamaan ibu dengan bayinya di dalam masa kehamilan.Ibu juga terlihat sangat senang dengan adanya sesi relaksasi dan meditasi yang membuat ibu nyaman serta dapat menghubungkan ibu dengan bayi yang dikandungnya.Sesi latihan ini sangat dinikmati oleh ibu sehingga ibu seringkali menerapkan teknik ini saat dirumah. Pada intinya adalah latihan prenatal yoga memiliki prinsip penyatuan tubuh, pikiran dan jiwa sehingga penerapan prinsip tersebut dalam prenatal yoga menjadi keunggulan yang lebih dibandingan kegiatan latihan sejenis dimasa kehamilan seperti senam hamil.

\section{Kesimpulan}

Terdapat pengaruh yang signifikan pada kelompok ibu hamil yang melakukan prenatal yoga dan senam hamil terhadap kesiapan fisik,. Hasil penelitian juga mengungkapkan kegiatan prenatal yoga memiliki nilai hubungan pengaruh yang lebih tinggi dibandingkan dengan ibu yang melakukan senam hamil dengan berdasarkan hasil pengukuran dari skor kesiapan fisik ibu hamil

\section{Saran}

Saran pada penelitian ini yaitu diperlukan adanya peningkatan penerapan 
cakupan kegiatan latihan prenatal yoga mengingat besar nya manfaat yang dihasilkan dari kegiatan prenatal yoga serta dapat menjangkau setiap lapisan pelayanan kesehatan ibu dan anakserta latihan prenatal yoga ini dapat menjadi pilihan utama dalam peningkatan kesehatan fisik dan kecemasan pada ibu hamil. Serta diharapkan prenatal yoga menjadi salah satu pilihan utama bagi ibu hamil untuk meningkatkan kesehatan ibu dan anak.

\section{Daftar Pustaka}

1. Carson C, et al. Complementary Care : Treatment Options for Cancer Patients.Cancer Fitness Programs, Healthlinks, Boulder, Colorado. 2004.

2. Stillman S. Yoga as a treatment for reducing maternal stress and negative birth outcomes. Bernard College. pp.1-14. 2012.

3. Narendran et al. Efficacy of yoga on pregnancy outcome. Journal of Alternative and Complementary Medicine,vol. 11, no. 2, pp. 237-244, 2005.

4. Jiang Q, et al. Effects of Yoga Intervention during Pregnancy: A Review for Current Status. American Journal of Perinatology, 32(6), pp.503-514. 2015.

5. Chuntharapat $\mathrm{W}$, et al. Yoga during pregnancy: effects on maternal comfort, labor pain and birth outcomes.Journal of Complementary Therapies in Clinical Practice, vol. 14, no. 2, pp. 105-115, 2008.

6. A. E. Beddoe, et al. The effects of mindfulness based yoga during pregnancy on maternal psychological and physical disstress. Journal of Obstetric Gynecologic, and Neonatal Nursing vol. 38 no. 3 pp. $310-319.2009$.

7. Rakhshani A, et al. The effects of yoga in prevention of pregnancy complications in highrisk pregnancies: A randomized controlled trial. Preventive Medicine, 55(4), pp.333-340. 2012.

8. Sun Y, et al. Effects of a prenatal yoga program on the discomforts of pregnancy and maternal childbirth self-efficacy in Taiwan. Midwifery, 26(6),pp.e 31-e 36. 2010.

9. Yulaikhah L. Seri Asuhan Kebidanan Kehamilan. Jakarta : EGC; 2008.

10. Hulliana M. Panduan Menjalani Kehamilan Sehat. Jakarta: Puspa Swara; 2007.

11. Farida dan Sunarti. Senam Hamil Sebagai Upaya Untuk Memperlancar Proses Persalinan di Rumah Sakit Kasih Ibu Surakarta. Info Kes Vol 5 No 1. Jurnal Ilmiah Rekam Medis dan Informasi Kesehatan. ISSN 2086-2628. 2015.

12. Damayanti SY. Hubungan antara senam hamil dengan kejadian persalinan lama (Studi di Rumah Bersalin Bhakti Ibu Semarang. Thesis.
Fakultas Ilmu Kesehatan Masyarakat Universitas Diponegoro. 2006.

13. Martini R. Herlyssa dan Eugenie, T. Pengaruh Senam Hamil Terhadap Lamanya Persalinan di Puskesmas Kecamatan Palmerah Jakarta Barat. Jurnal Madya Vol. 4 . 2008.

14. Sastroasmoro $S$ dan Sofyan Ismael. Dasar-Dasar Metodologi Penelitian Klinis Edisi Ketiga. In :Pemilihan Subjek Penelitian dan Desain Penelitian.Jakarta : Sagung Seto, 78-100; 2010.

15. Aprillia. Prenatal Gentle Yoga. Jakarta : Medika Kesehatan; 2011.

16. Manuaba. Ilmu Kebidanan, penyakit Kandungan dan KB untuk Pendidikan Bidan Edisi 2. Jakarta : EGC; 2010

17. Kluge $J$. et al. International Journal of Gynecology and Obstetrics Speci fi c exercises to treat pregnancy-related low back pain in a South African population. , 113, pp.187-191. 2011

18. Szumilewicz A. et al.,. Influence of prenatal physical activity on the course of labour and delivery according to the new Polish standard for perinatal care. , 20(2), pp.380-389. 2013

19. Rusmita E. Pengaruh Senam Hamil Yoga Selama Kehamilan Terhadap Kesiapan Fisik dan Psikologis dalam Menghadapi Persalinan Pada Ibu Hamil Trimester III di RSIA Limijati Jantung., (906594942), pp.1-90. 2011.

20. Mulyata. Paket Penyuluhan Kognitif dan Senam Prapersalinan Mengurangi Cemas dan Nyeri Persalinan. Disertasi Thesis, Universitas Airlangga. 2007.

21. Morgan L. Conceptualizing Women Centered Care in Miwifery. Volume I4, Numéro 1, Printemps (April). 2015. 